\title{
Model Pembelajaran OIDDE pada Matakuliah Pengetahuan Lingkungan untuk Meningkatkan Keterampilan Berpikir Kritis Mahasiswa Calon Guru Biologi
}

\author{
Husamah a, ${ }^{*}$, Diani Fatmawati a, ${ }^{2}$, Dwi Setyawan a, 3 \\ ${ }^{a}$ Universitas Muhammadiyah Malang, Jalan Raya Tlogomas 246, Malang, Jawa Timur 65144, Indonesia \\ 1 husamahumm@gmail.com*; dianifatmawati87@gmail.com; dwis091187@gmail.com \\ *korespondensi penulis
}

\begin{abstract}
ABSTRAK
Pembelajaran yang diterima mahasiswa calon guru biologi harus mendorong untuk berpikir kritis dan mampu menjadi problem solver. Salah satu pembelajaran yang secara teoritis dapat menstimulasi berpikir kritis adalah model pembelajaran OIDDE (Orientation, Identify, Discussion, Decision, dan Engage in behavior). Penelitian ini bertujuan mendeskripsikan penerapan model pembelajaran OIDDE dan menganalisis peningkatan sepuluh indikator keterampilan berpikir kritis. Jenis penelitian merupakan Penelitian Tindakan Kelas yang dilaksanakan dengan Lesson Study. Subjek penelitian adalah 47 mahasiswa semester $\mathrm{V}$ yang menempuh mata kuliah Pengetahuan Lingkungan di Program Studi Pendidikan Biologi Universitas Muhammadiyah Malang. Penelitian dilaksanakan dalam 2 siklus tindakan, setiap siklus terdiri dua kali pertemuan selama 3x50 menit. Masing-masing pertemuan dilaksanakan dengan Lesson Study yang memenuhi tahap Plan, Do, dan See serta digabungkan dengan tindakan kelas. Analisis data dilakukan secara deskriptif kualitatif, didukung dengan data kuantitatif. Hasil penelitian menunjukkan bahwa 1) model pembelajaran OIDDE telah dilaksanakan sesuai sintaks, ada perbaikan proses pada tiap siklus, dan 2) kesepuluh indikator keterampilan berpikir kritis mengalami peningkatan, yaitu tujuan 16,9\%, permasalahan 17,8\%, menyikapi masalah 22,3\%, sudut pandang 24,3\%, informasi $19,5 \%$, konsep $21,2 \%$, asumsi $12,5 \%$, alternatif solusi $8,1 \%$, interpretasi $21,0 \%$, dan implikasi $21,8 \%$. Semua indikator pada siklus 2 berdasarkan rerata termasuk dalam kategori sangat baik.
\end{abstract}

Kata kunci: berpikir kritis, mahasiswa calon guru biologi, mata kuliah lingkungan, model pembelajaran OIDDE

\begin{abstract}
OIDDE Learning Model in Environmental Science Course to Increase Critical Thinking Skills of Students of Biology Teacher Candidate. Learning received by biology teacher candidates students should encourage them to think critically and become problem solver. The learning model that theoretically could stimulate critical thinking is the OIDDE (Orientation, Identify, Discussion, Decision, dan Engage in behavior). This study aim to describe the application of OIDDE learning model and to analyze the improvement of ten indicators of critical thinking skills. This research was a Classroom Action Research that conducted with Lesson Study. The research subject is 47 students, semester V, who take Environmental Science course in Biology Education Department, University of Muhammadiyah Malang. The study was conducted in 2 cycles, each cycle consisting of two meetings for 3x50 minutes. Each meeting is carried out with Lesson Study stages of Plan, Do, and See and combined with classroom action research. The data were analyzed descriptively qualitative supported with quantitative data. The results show that 1) OIDDE learning model has been implemented in according to syntax, the process improved in each cycle, and 2) ten indicators of critical thinking skills have increased, i.e. objective $16.9 \%$, problem $17.8 \%$, address the problem $22.3 \%$, viewpoint $24.3 \%$, information $19.5 \%$, concept $21.2 \%$, assumption $12.5 \%$, alternative solution $8.1 \%$, interpretation $21.0 \%$, and implications $21.8 \%$. All indicators in cycle 2 based on the average are excellent category.
\end{abstract}

Keyword: biology teacher candidate students, critical thinking, environmental course, OIDDE learning model.

Copyright (C) 2017 Universitas Ahmad Dahlan. All Right Reserved

\section{Pendahuluan}

Zaman modern saat ini ditandai kemajuan ilmu pengetahuan dan teknologi di segala bidang. Kemajuan teknologi menghasilkan berbagai produk dan jasa untuk memenuhi aneka kebutuhan manusia. Namun demikian, produk atau hasil temuan tersebut diikuti munculnya berbagai masalah etika, salah satunya di bidang biologi dan rumpun keilmuannya, termasuk ekologi dan lingkungan hidup (Minarno, 2012). Permasalahan lingkungan telah menjadi isu global dan masalah kronis di Indonesia
(Hartiwiningsih, 2009; Turista, 2017; Yafie, 2006). Pencemaran, kerusakan sumberdaya alam, kebakaran hutan, tanah longsor, banjir, perubahan cuaca, dan pemanasan global beberapa dekade terakhir muncul karena dampak dari berbagai aktivitas manusia (Khoiriyah \& Ristianti, 2011; Prasetiyo \& Perwiraningtyas, 2017). Permasalahan lingkungan muncul karena ketidakmampuan manusia dalam mengembangkan tata nilai yang baik, gaya hidup, etika, kemampuan berpikir kritis, dan pola berpikir harmonis dengan lingkungan (Arslan, 2012; Husamah Husamah, 2015; Quinn, 2012). Selain 
terkait permasalahan lingkungan, menghasilkan ide dan strategi pengembangan lingkungan juga membutuhkan adanya kemampuan berpikir kritis (Puspitasari, Sumarmi, \& Amirudin, 2016).

Berdasarkan kenyataan adanya problematika lingkungan yang terus berkembang, maka di Program Studi Pendidikan Biologi Fakultas Keguruan dan Ilmu Pendidikan Universitas Muhammadiyah Malang (FKIP UMM) setiap mahasiswa - yang merupakan calon guru masa depan - diwajibkan untuk menempuh matakuliah Pengetahuan Lingkungan (bernilai 3 SKS dan ditempuh pada semester V). Capaian pembelajaran matakuliah Pengetahuan Lingkungan adalah "mahasiswa mampu menganalisis konsep-konsep pengetahuan lingkungan untuk terampil mengaplikasikan kepekaan terhadap permasalahan lingkungan dalam bentuk proyek dan kajian/penelitian sesuai etika, norma, dan sikap ilmiah”.

Berdasarkan observasi awal yang telah dilakukan di kelas D, semester 5, angkatan 2013/2014 pada tanggal 27 September dan 4-18 Oktober 2016, refleksi bersama dosen pengampu, refleksi bersama para observer, analisis terhadap rekaman proses pembelajaran, analisis jurnal/catatan mengajar dosen, analisis terhadap catatan refleksi pembelajaran yang ditulis mahasiswa, dan wawancara dengan beberapa mahasiswa secara acak didapatkan hasil, yaitu; 1) proses pembelajaran yang dilaksanakan belum diarahkan untuk mengembangkan kemampuan berpikir kritis. Perkuliahan hanya dilaksanakan dengan ceramah, diskusi, dan penugasan tertentu dan tidak dirancang secara sengaja untuk mengembangkan kemampuan berpikir kritis; 2) mahasiswa belum dikondisikan dalam sebuah pendekatan pembelajaran yang inovatif dan konstruktif, yang menekankan belajar kontekstual melalui kegiatan-kegiatan yang kompleks; 3) mahasiswa belum dikondisikan pada situasi yang menantang atau masalah yang melibatkan solusi, pengambilan keputusan, refleksi, dan pengambilan inisiatif dengan difasilitasi dosen; 4) motivasi mahasiswa dalam belajar masih rendah, hal ini dapat diketahui dari ketidakantusiasan mahasiswa dalam mengikuti proses pembelajaran, banyak mahasiswa yang tidak memperhatikan penjelasan dosen maupun penjelasan temannya yang lain pada saat proses pembelajaran berlangsung; 5) mahasiswa lebih tertarik atau senang ketika kegiatan pembelajaran berupa diskusi, namun kegiatan tersebut belum terkondisikan secara sistematis sehingga tidak terarah; 6) mahasiswa belum diminta untuk mengaitkan pengetahuan yang telah miliki dengan materi yang akan mereka pelajari atau menyadari apa yang telah mereka ketahui dari materi yang akan dipelajari; dan 7) mahasiswa belum diminta untuk mengembangkan kemampuan berpikir, memiliki keberanian untuk menyanggah atau mengkritisi isu-isu bidang lingkungan yang muncul di kelas, dan melakukan refleksi atas pembelajaran yang mereka lakukan.

Program Studi Pendidikan Biologi Fakultas Keguruan dan Ilmu Pendidikan Universitas Muhammadiyah Malang (FKIP UMM) adalah salah satu program studi yang mencetak lulusannya menjadi calon guru biologi profesional jenjang pendidikan menengah di masa depan (Hudha, 2015; Husamah Husamah, 2015). Sehubungan dengan tuntutan pendidikan, salah satu prinsip pembelajaran yang dilaksanakan harus bersifat mendalam dan komprehensif untuk menyelesaikan masalah (Afandi, Sugiyarto, \& Sunarno, 2012; Pary, 2010), maka Program Studi Pendidikan Biologi harus menerapkan strategi-strategi atau model-model pembelajaran yang mendorong pengembangan dan pemberdayaan keterampilan berpikir (Setyawan, 2017). Mahasiswa harus terlatih untuk mempergunakan kekuatan daya pikir, alih-alih kekuatan fisik konvensional (BSNP, 2010). Mahasiswa harus memiliki kompetensi lengkap, kemampuan berpikir kritis, kepekaan tinggi, rasa peduli, etika, dan wawasan yang luas, termasuk dalah hal ini terkait lingkungan hidup zaman modern (H. Husamah, 2015; Husamah Husamah, 2015; Setyaningrum \& Husamah, 2011).

Keterampilan berpikir kritis tentu tidak muncul dengan tiba-tiba (Arslan, 2012; Rosnawati, 2012). Sebagaimana hakikatnya, keterampilan berpikir kritis (selayaknya semua kemampuan berpikir) secara umum tidak dapat berkembang secara alamiah karena keterampilan berpikir kritis harus diperkaya oleh berbagai stimulus lingkungan dan suasana yang beragam. Berpikir adalah suatu proses kognitif atau aktivitas mental untuk memperoleh pengetahuan. Peningkatan keterampilan berpikir kritis memerlukan lingkungan dan atmosfer pembelajaran yang dapat menstimulasi (Husamah Husamah, 2016). Berdasarkan paparan tersebut dapat diketahui bahwa keterampilan berpikir kritis perlu untuk diberdayakan atau distimulus. Pembiasaan atau stimulus ini tidak dapat terlaksana apabila hanya dalam suasana, strategi, dan model pembelajaran konvensional. Oleh karena itu, diperlukan upaya secara sistematis sebagai alternatif yatiu salah satunya melalui penerapan model pembelajaran OIDDE.

Model pembelajaran yang diduga layak (valid), praktis dan efektif secara teoritis untuk diterapkan dalam pengembangan kemampuan berpikir kritis adalah model pembelajaran OIDDE (Hudha, Amin, Bambang, \& Akbar, 2016b). Model pembelajaran OIDDE (Orientation, Identify, Discussion, 
Decision, dan Engage in behavior) dimungkinkan mendukung teori bahwa pembelajaran yang diberikan harus meningkatkan aktivitas mahasiswa untuk menemukan dan memecahkan masalah, bekerja kooperatif, memiliki sikap etis dan mampu mengambil keputusan etis atas problematika etis yang dihadapi (Hudha, Amin, Bambang, \& Akbar, 2016a). Mahasiswa diharapkan mampu menemukan dan memecahkan masalah serta mengambil keputusan etis dengan tepat berkaitan dengan kemampuan berpikir kritis.

Berpikir kritis adalah proses terorganisasi yang melibatkan aktivitas mental dalam perumusan masalah, memberikan argumen, melakukan deduksiinduksi, serta evaluasi untuk memecahkan masalah. Indikator-indikator berpikir kritis yaitu formulasi bentuk pertanyaan ke arah jawaban, argumen dengan alasan sesuai, interpretasi pernyataan, mengemukakan asumsi logis, dan evaluasi berdasar fakta (Agustina \& Susantini, 2010; Arnyana, 2004). Berdasarkan hal tersebut, secara teoritis terdapat keterkaitan antara indikator berpikir kritis dengan Model Pembelajaran OIDDE.

Pembelajaran dikemas berbasis Lesson Study (LS), meliputi perencanaan (plan), tindakan pembelajaran (do), dan evaluasi (see). LS menyediakan proses untuk berkolaborasi dalam proses pembelajaran sambil memeriksa strategi yang tepat untuk meningkatkan kompetensi siswa. Dalam proses LS, pengajar bekerja sama untuk merencanakan, melaksanakan pembelajaran, dan mengamati. LS membudayakan aspek kooperatif, sementara satu pengajar melaksanakan pembelajaran di kelas, yang lain mengamati dan mencatat pada pertanyaan-pertanyaan, pemahaman, dan temuan menarik lainnya (Lewis, 2002).

LS memberikan banyak manfaat, yaitu meningkatkan pengetahuan tentang materi dan proses pembelajaran, meningkatkan pengetahuan tentang cara mengobservasi aktivitas belajar, menguatnya hubungan kolegalitas, menguatnya hubungan antara pelaksanaan pembelajaran seharihari dengan pembelajaran jangka panjang, meningkatnya motivasi untuk senantiasa berkembang, dan meningkatnya kualitas rencana dan komponen pembelajaran (Syamsuri \& Ibrohim, 2011). Perbaikan proses pembelajaran merupakan sesuatu yang terus-menerus perlu ditingkatkan, agar efektivitas dan efisiensi pembelajaran terus meningkat. Perbaikan proses merupakan konsekuensi dari penerapan evaluasi pelaksanaan pembelajaran dan penerapan sistem umpan-balik pada proses pembelajaran (Kusni, 2010).

Sehubungan dengan itu tujuan penelitian ini, yaitu 1) mendeskripsikan penerapan model pembelajaran OIDDE pada matakuliah Pengetahuan Lingkungan dan 2) menganalisis peningkatan keterampilan berpikir kritis mahasiswa melalui penerapan model pembelajaran OIDDE pada matakuliah Pengetahuan Lingkungan. Penelitian ini diharapkan memiliki manfaat teoretis dan praktis, yaitu 1) meningkatkan kualitas pembelajaran di Prodi Pendidikan Biologi FKIP UMM; 2) menjadi acuan atau literatur kajian dan penelitian selanjutnya terkait penerapan model pembelajaran OIDDE, pengembangan kemampuan berpikir kritis, dan 3) menjadi dasar bagi guru, dosen, dan atau para pengajar dalam menerapkan atau mengimplementasikan model pembelajaran OIDDE dalam pembelajaran yang dilakukan.

\section{Metode Penelitian}

Jenis penelitian ini merupakan Penelitian Tindakan Kelas (PTK). Pendekatan dalam penelitian ini adalah pendekatan kualitatif. Subjek penelitian adalah 47 orang mahasiswa semester V, kelas D yang menempuh mata kuliah Pengetahuan Lingkungan pada tahun ajaran 2016/2017. Penelitian ini dilaksanakan dalam 2 siklus tindakan. Setiap siklus terdiri atas dua kali pertemuan selama 3 jam pelajaran (3x50 menit). Materi yang dibahas pada Siklus 1 adalah Pencemaran Lingkungan (air, tanah, dan udara), sedangkan pada Siklus 2 materi yang dibahas adalah Strategi Pengembangan Lingkungan.

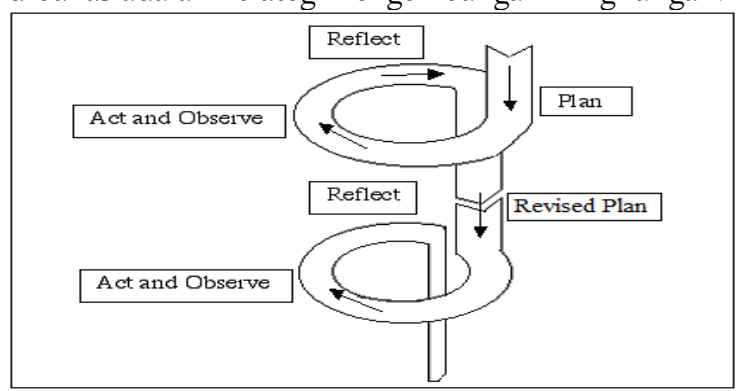

Gambar I. Spiral model dalam penelitian tindakan kelas

Setiap siklus tindakan yang dilaksanakan terdiri atas empat tahapan mengadopsi Spiral Model dari Kemmis, McTaggart, \& Nixon (2013) yaitu planning, implementing, observing, dan reflecting, dapat dilihat pada Gambar 1.

Pada penelitian ini setiap siklus dilaksanakan dengan LS yang mengacu pada Lewis (2002), yaitu memenuhi 3 tahapan plan, do, dan see. Menurut Susilo (2009) kombinasi PTK dan LS merupakan sarana untuk mengembangkan keprofesionalan pendidik karena melalui PTK pendidik dapat memecahkan masalah-masalah pembelajaran di kelas, sekaligus melalui LS pendidik dapat mengamati bagaimana peserta didik belajar. Siklus dalam LS dapat dilihat pada Gambar 2. 


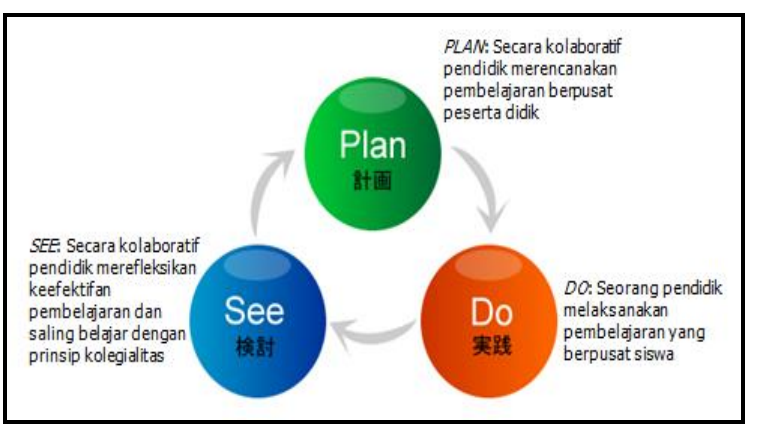

Gambar 2. Siklus pengkajian pembelajaran dalam lesson study di Indonesia

Tabel I. Perpaduan TPK dan LS

\begin{tabular}{|c|c|c|}
\hline PTK & $L S$ & Kegiatan \\
\hline \multicolumn{3}{|l|}{ Siklus I } \\
\hline \multirow[t]{7}{*}{ Perenca-naan } & Plan I Awal Siklus I & Identifikasi masalah dan penyebabnya \\
\hline & & Membuat RPP materi pencemaran lingkungan \\
\hline & & Membuat instrumen penelitian berupa lembar observasi \\
\hline & & Membuat rubrik penilaian dan angket \\
\hline & & Menyiapkan perangkat evaluasi dan authentic assesment \\
\hline & & Mempresentasikan perangkat yang telah dibuat \\
\hline & & Revisi perangkat berdasarkan masukan tim \\
\hline \multirow[t]{3}{*}{$\begin{array}{l}\text { Tindakan } \\
\text { Observasi /Penga-matan }\end{array}$} & Do $I$ & $\begin{array}{l}\text { Melaksanakan tindakan yang tertuang dalam RPP materi } \\
\text { pencemaran lingkungan }\end{array}$ \\
\hline & & $\begin{array}{l}\text { Mengamati aktivitas mahasiswa dalam menerima tindakan dari } \\
\text { peneliti selama proses pembelajaran }\end{array}$ \\
\hline & & $\begin{array}{l}\text { Menggunakan instrumen penelitian untuk melihat capaian tiap } \\
\text { tindakan }\end{array}$ \\
\hline \multirow[t]{2}{*}{ Refleksi } & See & $\begin{array}{l}\text { Menganalisis hasil observasi melalui diskusi balikan, dan instrumen } \\
\text { yang terkumpul }\end{array}$ \\
\hline & & $\begin{array}{l}\text { Pemberian umpan balik dari observer untuk perbaikan tindakan dan } \\
\text { peningkatan kualitas pada pertemuan berikutnya }\end{array}$ \\
\hline \multicolumn{3}{|l|}{ Siklus II } \\
\hline \multirow[t]{7}{*}{ Perencana-an } & Plan II & $\begin{array}{l}\text { Identifikasi masalah dan penyebabnya berdasarkan catatan/masukan } \\
\text { refleksi Siklus I }\end{array}$ \\
\hline & & Membuat RPP materi strategi pengembangan lingkungan \\
\hline & & Membuat instrumen penelitian berupa lembar observasi \\
\hline & & Membuat/merevisi rubrik penilaian dan angket \\
\hline & & Menyiapkan perangkat evaluasi dan authentic assesment \\
\hline & & Mempresentasikan perangkat yang telah dibuat \\
\hline & & Revisi perangkat berdasarkan masukan tim \\
\hline \multirow{4}{*}{$\begin{array}{l}\text { Tindakan } \\
\text { Observasi/penga-matan }\end{array}$} & Do II & Melaksanakan tindakan yang tertuang dalam RPP materi strategi \\
\hline & & pengembangan lingkungan. \\
\hline & & $\begin{array}{l}\text { Mengamati aktivitas mahasiswa dalam menerima tindakan dari } \\
\text { peneliti selama proses pembelajaran }\end{array}$ \\
\hline & & $\begin{array}{l}\text { Menggunakan instrumen penelitian untuk melihat capaian tiap } \\
\text { tindakan }\end{array}$ \\
\hline \multirow[t]{3}{*}{ Refleksi } & See II Pertemuan II (See Besar) & $\begin{array}{l}\text { Menganalisis hasil observasi melalui diskusi balikan, dan instrumen } \\
\text { yang terkumpul }\end{array}$ \\
\hline & & Pemberian umpan balik dari observer untuk perbaikan tindakan dan \\
\hline & & $\begin{array}{l}\text { peningkatan kualitas pada pertemuan berikutnya (pertemuan kedua) } \\
\text { Menganalisis hasil observasi melalui diskusi balikan, dan instrumen } \\
\text { vang terkumpul }\end{array}$ \\
\hline
\end{tabular}

Perpaduan antara PTK dan LS yang telah dirancang dan dilaksanakan, seperti pada Tabel 1. Pengelolaan data meliputi kegiatan mengelola data mentah, menyajikan data, menarik kesimpulan dan melakukan refleksi. Dalam penelitian ini data diperoleh melalui observasi berupa aktivitas pembelajaran yang dilakukan oleh dosen dan mahasiswa. Data keterampilan berpikir kritis diperoleh melalu angket keterampilan berpikir kritis merujuk Marzano yang dimodifikasi oleh Sidharta \& Darliana (2005).
Angket yang telah dimodifikasi tersebut juga telah digunakan oleh Husamah \& Pantiwati (2014) dalam penelitian yang dilakukan dan hasilnya telah dipublikasikan. Angket tersebut dibagikan setiap akhir siklus, mahasiswa diminta untuk mengisi angket selama \pm 10 menit. Khusus untuk mengukur kemampuan berpikir kritis awal mahasiswa, angket diberikan pada saat observasi. Analisis data dilakukan secara deskriptif kualitatif yang didukung dengan data kuantitatif berupa persentase skor keterampilan berpikir kritis. Untuk mengetahui persentase skor keterampilan berpikir kritis secara klasikal dapat dihitung dengan menggunakan rumus Arikunto (2001) sebagai berikut.

$$
\text { Persentase Skor }=\frac{\text { Jumlah } \text { skor yang diperoleh }}{\text { Jumlah skor maksimal }} \times 100 \%
$$

Peningkatan skor setiap indikator keterampilan berpikir kritis dilakukan dengan menghitung selisih persentase antara Siklus II dengan tahap Prasiklus. 


\section{Hasil dan Pembahasan}

\section{Penerapan Model Pembelajaran OIDDE}

Berdasarkan hasil pengamatan terhadap proses pembelajaran yang dilaksanakan oleh dosen model, refleksi terhadap catatan para observer, review Tabel 2. Pelaksanaan fase/tahap model OIDDE

\begin{tabular}{|c|c|c|}
\hline Fase / tahap & Kegiatan Dosen & Kegiatan Mahasiswa \\
\hline Orienta-tion & $\begin{array}{l}\text { Menyiapkan dan mengarahkan mahasiswa untuk belajar } \\
\text { permasalahan pencemaran lingkungan (siklus 1) dan } \\
\text { permasalahan terkait pengembangan lingkungan (siklus 2). } \\
\text { Menugaskan mahasiswa secara individu untuk menuliskan } \\
\text { temuan persoalan dilemma etis lingkungan dari materi yang } \\
\text { disampaikan. } \\
\text { Menyajikan materi/film dan memberikan penguatan orientasi } \\
\text { mahasiswa melalui penyampaian cerita dilemma pencemaran } \\
\text { lingkungan pada siklus } 1 \text { dan dilemma terkait pengembangan } \\
\text { lingkungan pada siklus } 2 \text {. }\end{array}$ & $\begin{array}{l}\text { Menyiapkan dirinya untuk belajar mengenai materi } \\
\text { yang diajarkan oleh dosen (berkaitan dengan } \\
\text { permasalahan pencemaran lingkungan pada siklus } 1 \\
\text { dan permasalahan terkait pengembangan lingkungan } \\
\text { pada siklus 2). } \\
\text { Menerima materi pembelajaran dari pendidik dengan } \\
\text { mendengarkan, mencermati dan mencatat dengan } \\
\text { seksama. } \\
\text { Menuliskan persoalan dilematis permasalahan yang } \\
\text { ditemukan }\end{array}$ \\
\hline Identify & $\begin{array}{l}\text { Membagi mahasiswa dalam kelompok kecil (4-5 orang) secara } \\
\text { heterogen } \\
\text { Menugaskan mahasiswa secara individu untuk } \\
\text { mengidentifikasi hal-hal dilematis yang muncul atas } \\
\text { permasalahan pada materi yang pelajari (disampaikan) sebagai } \\
\text { bahan utama diskusi kelompok. } \\
\text { Mengarahkan mahasiswa (pada setiap kelompok) untuk } \\
\text { memberikan penjelasan tentang persoalan dilematis atas } \\
\text { permasalahan yang dipelajari yang berhasil didentifikasi dan } \\
\text { dipilih sebagai topik diskusi. } \\
\text { Mempertanyakan nilai-nilai kontradiksi yang ditemukan } \\
\text { dari dilema yang diidentifikasi. }\end{array}$ & $\begin{array}{l}\text { Membentuk kelompok kecil (4-5 orang) sesuai } \\
\text { arahan dosen } \\
\text { Secara individu melakukan identifikasi persoalan } \\
\text { dilemma permasalahan lingkungan } \\
\text { Bersama kelompok: 1) memeriksa fakta-fakta dari } \\
\text { kasus dilematis; 2) membuat pertanyaan terhadap } \\
\text { kasus dilematis yang diidentifikasi; 3) membuat } \\
\text { sintesis antara fakta-fakta dengan kasus dilematis } \\
\text { yang diidentifikasi; } 4 \text { ) memilih isu dilematis } \\
\text { prioritas; 5) mengidentifikasi nilai-nilai kontradiksi } \\
\text { dari isu dilematis yang dipilih sebagai bahan diskusi. } \\
\text { Menjelaskan isu dilematis prioritas yang dipilih. }\end{array}$ \\
\hline Discussion & $\begin{array}{l}\text { Menjadi fasilitator dan mediator dalam diskusi kelompok. } \\
\text { Mengarahkan setiap kelompok diskusi untuk melakukan } \\
\text { diskusi membahas isu dilematis prioritas atas problematika } \\
\text { lingkungan. } \\
\text { Meminta dan memandu masing-masing kelompok diskusi } \\
\text { untuk presentasi hasil diskusi. }\end{array}$ & $\begin{array}{l}\text { Melaksanakan diskusi terhadap isu dilematis } \\
\text { prioritas atas permasalahan yang dipelajari. } \\
\text { Setiap kelompok menetapkan peran terhadap isu } \\
\text { dilematis yang dipelajari. } \\
\text { Memberikan penjelasan alasan mendasar mengapa } \\
\text { memilih posisi (peran) tersebut. } \\
\text { Menyajikan hasil diskusi kelompok di depan kelas. } \\
\text { Melakukan diskusi kooperatif dengan kelompok lain. } \\
\text { Menyusun hasil diskusi sebagai dasar pengambilan } \\
\text { keputusan. }\end{array}$ \\
\hline Decision & $\begin{array}{l}\text { Mengarahkan kelompok diskusi untuk mengambil keputusan } \\
\text { pemecahan masalah dilematis atas permasalahan yang } \\
\text { dipelajari. } \\
\text { Menugaskan kelompok diskusi untuk menetapkan keputusan } \\
\text { dari isu dilematis atas problematika yang dipelajari. } \\
\text { Meminta kelompok untuk menyampaikan hasil diskusi dan } \\
\text { keputusan yang telah diambil. }\end{array}$ & $\begin{array}{l}\text { Merencanakan proses pengambilan keputusan isu } \\
\text { dilematis atas permasalahan yang dipelajari. } \\
\text { Menetapkan keputusan isu dilematis atas } \\
\text { permasalahan a etika yang dipelajari didasarkan pada } \\
\text { posisi (peran) yang ditentukan (dipilih). } \\
\text { Menyampaikan hasil keputusan atas permasalahan } \\
\text { yang dipelajari sesuai peran yang diambil. }\end{array}$ \\
\hline $\begin{array}{l}\text { Engage in } \\
\text { behavior }\end{array}$ & $\begin{array}{l}\text { Mengarahkan mahasiswa secara individu untuk berperilaku } \\
\text { sebagaimana keputusan yang ditetapkan secara verbal (lisan) } \\
\text { dengan menuliskan perilaku dimaksud. } \\
\text { Mengarahkan mahasiswa untuk menyimpulkan hasil } \\
\text { pembelajaran vang telah dilaksanakan secara bersama-sama }\end{array}$ & $\begin{array}{l}\text { Menuliskan tindakan sebagai gambaran perilaku yang } \\
\text { dilakukan dari hasil keputusan yang ditetapka, } \\
\text { Membuat kesimpulan atas materi yang telah } \\
\text { dipelajari secara bersama-sama. }\end{array}$ \\
\hline
\end{tabular}

terhadap rekaman video selama proses pembelajaran Siklus I dan Siklus II, maka didapatkan data pelaksanaan fase/tahap model pembelajaran OIDDE. Data pelaksanaan tersebut seperti disajikan pada Tabel 2. 
melakukan proses Identify, dimana mereka harus mengidentifikasi serta menentukan konsep-konsep problematika lingkungan hidup berdasarkan tayangan atau informasi yang diberikan dosen sebelumnya. Selain itu, mahasiswa juga harus membuat argumen tentang konsep-konsep problematika lingkungan yang didukung dengan bukti-bukti atau dasar teori yang relevan. Proses ini tentu saja membutuhkan kemampuan berpikir kritis yang baik, yang apabila belum terbiasa akan membutuhkan waktu relatif lama.

Identifikasi masalah sebagai rangkaian dalam berpikir membutuhkan waktu relatif lebih lama, terlebih bagi mereka yang belum terbiasa (Karjalainen, Alha, \& Jutila, 2006). Sebagai bagian dari proses berpikir, mengidentifikasi masalah membutuhkan kosentrasi yang cukup tinggi sehingga membutuhkan waktu, terlebih jika sebelumnya peserta didik telah terkosentarsi dalam banyak hal (Saragih, 2008).

Menurut Yuliana (2015) mengingat proses identifikasi masalah memerlukan waktu berpikir relatif lama maka sebaiknya pengajar/dosen perlu menyajikan masalah dengan cara dan bentuk yang menarik. Konteks permasalahan yang disampaikan harus dikenal baik oleh mahasiswa dan harus menarik perhatian serta membangkitkan semangat intelektual. Pengajar/dosen juga perlu memberikan waktu yang cukup kepada mahasiswa untuk mengeksplorasi masalah. Pengajar/dosen harus memperhitungkan waktu yang dibutuhkan untuk memecahkan masalah, mendiskusikan kemungkinan pemecahannya, dan merangkum apa yang telah dipelajari.

Terkait dengan permasalahan tersebut perbaikan yang dilakukan oleh dosen pada Siklus II adalah dengan memunculkan permasalahan yang lebih menarik, umum dikenal dan dijumpai dalam kehidupan sehari-hari mahasiswa, dan dikemas dalam bentuk video sehingga lebih menarik bagi mahasiswa. Dosen model juga melakukan disiplin waktu pada tahap-tahap lainnya, khususnya fase/tahap diskusi. Diskusi yang menarik cenderung memakan banyak waktu karena setiap mahasiswa aktif untuk menyampaikan pendapat atau gagasannya. Namun demikian, diskusi yang tidak terarah jika dibiarkan juga akan semakin memakan lebih banyak waktu, sehingga dosen harus berkonsentrasi dan disiplin mengatur peruntukan waktu setiap fase/tahap.

Berdasarkan masukan terhadap pelaksanaan Siklus I, dosen model mengatur dengan tepat peruntukan waktu untuk fase Discussion atau diskusi. Dosen model melakukan pengaturan atau pengalokasian waktu presentasi dengan tepat, waktu bertanya, menanggapi, dan menyanggah. Hal ini dapat dilakukan karena pada mata kuliah Pengetahuan Lingkungan satu pertemuan terdiri dari 3 jam pelajaran, dan 1 jam pelajaran berdurasi 50 menit, sehingga total waktu adalah 150 menit. Langkah yang sama berupa pengalokasian waktu secara tepat juga dilakukan oleh Fariati, Hudha, \& Husamah (2017). Hal ini tentu sejalan dengan pandangan Djamarah (2000) bahwa dalam menerapkan diskusi para guru/dosen harus berhatihati. Diskusi yang di dalamnya terdapat aktivitas membuat keputusan, diskusi kelompok kecil, serta kelompok besar akan memerlukan pertimbangan yang memakan waktu bahkan pemborosan waktu.

Perbaikan yang dilakukan dosen model terkait dengan waktu ditunjukkan bahwa pada siklus II waktu yang digunakan tepat 150 menit. Kedisiplinan mengelola waktu juga mendorong dosen model untuk patuh dan secara tepat melaksanakan semua kegiatan yang harus dilakukan dosen dan mahasiswa di setiap fase/tahap OIDDE. Pada Siklus II dosen model semakin mahir melaksanakan fase-fase pembelajaran OIDDE. Dosen model telah menyiapkan catatan kecil yang dapat dilihat sewaktu tentang apa yang harus ia lakukan dan mahasiswa lakukan setiap fasenya. Jika target capaian tidak maksimal dosen model melakukan improvisasi sehingga akhirnya target tersebut tercapai, misalnya apabila mahasiswa tidak mampu memberikan pemcahan yang tepat, maka dosen model memberikan pancingan berupa kata-kata kunci yang mendorong mahasiswa secara individu maupun kelompok untuk melakukan dan memikirkan hal tersebut.

Dosen model dan para observer juga memiliki catatan-catatan mengenai jalannya pembelajaran Siklus I, termasuk dalam hal ini adalah aktivitas mahasiswa secara individu maupun kelompok. Pada saat refleksi (see) Siklus I dan plan Siklus II, observer memberikan catatan-catatan mengenai aktivitas mahasiswa dan terutama hal-hal yang perlu diperbaiki sehubungan dengan permasalahan keaktifan tersebut. Observer memberikan alternatifalternatif cara untuk meningkatkan aktivitas mahasiswa dalam hal berpikir kritis, khususnya mahasiswa-mahasiswa yang perlu mendapatkan pendampingan dan perlu dilibatkan secara lebih dalam proses pembelajaran Interaksi antara dosen dan mahasiswa untuk merangsang aktivitas berpikir kritis mahasiswa juga dilakukan dosen model.

Peningkatan kualitas pembelajaran yang dilakukan dosen sebagai dampak positif dari perbaikan-perbaikan proses yang dilakukan berdasarkan masukan para observer melalui kegiatan Lesson Study juga mendorong peningkatan kualitas daya kritis atau kemampuan berpikir kritis 
mahasiswa, yang akan diuraikan sesuai data pada bagian berikutnya. Hal ini sejalan dengan Doig \& Groves (2011) serta Pantiwati (2015) bahwa Lesson Study yang diterapkan untuk meninjau sebuah aktivitas pembelajaran akan meningkatkan kualitas pembelajaran tersebut implementasi Lesson Study berdampak positif bagi pembinaan dan peningkatan kompetensi pedadogik.

Setelah mengikuti Lesson Study pengajar memiliki kemampuan yang memadai dalam merancang rencana pelaksanaan pembelajaran. Begitu juga kemampuan dalam melaksanakan kegiatan pembelajaran. Melalui kegiatan plan, pengajar mendapat masukan untuk perbaikan RPP sebelum disampaikan kepada mahasiswa. Pengajar berkesempatan merevisi RPP yang sudah dirancangnya. Ketika memasuki kelas, dalam kondisi siap dan percaya diri karena RPP yang "dibawa" merupakan hasil rancangan bersama pengajar sebidang dengan meminimalkan kemungkinan kendala yang dihadapi dalam pengelolaan pembelajaran. Kesiapan dalam perancangan rencana pembelajaran berdampak positif bagi pembelajaran menyenangkan dan efektif. Pembelajaran dilaksanakan secara sistematis dan terarah. Kehadiran observer untuk memantau kegiatan mahasiswa memungkinkan terdeteksinya kesulitan mahasiswa dalam belajar secara optimal dan merata. Kesulitan dan kelemahan selama pembelajaran dibahas dalam fase see untuk dicarikan solusi. Tahap-tahap yang dilalui dalam Lesson Study memungkinkan pengajar terus berkembang lebih baik (Rozak \& Fauziah, 2013).

\section{Peningkatan Keterampilan Berpikir Kritis melalui Penerapan Model Pembelajaran OIDDE}

Analisis dilakukan dengan menghitung skor masing-masing indikator yang diperoleh mahasiswa, kemudian digunakan untuk melihat persentase skor setiap aspek kemampuan berpikir kritis mahasiswa secara klasikal. Setelah menghitung persentase skor kemampuan berpikir kritis tersebut selanjutnya mengklasifikasikan skor tersebut ke dalam kategori kurang sekali $(<40 \%)$, kurang $(\geq 40-\leq 55 \%)$, cukup ( $>56-<66 \%)$, baik $(\geq 66-<80 \%)$, dan baik sekali $(\geq 80-100 \%)$ yang mengacu pada Arikunto (2005). Pada akhir perhitungan, diperoleh klasifikasi nilai secara klasikal untuk mengetahui kemampuan berpikir mahasiswa secara keseluruhan. Peningkatan skor setiap indikator keterampilan berpikir kritis dilakukan dengan menghitung selisih persentase Siklus II dengan Prasiklus. Data hasil kemampuan berpikir kritis mahasiswa pada Prasiklus dapat dilihat pada Tabel 3 .
Tabel 3. Data kemampuan berpikir kritis pada prasiklus

\begin{tabular}{lcc}
\hline \multicolumn{1}{c}{ Indikator } & Skor $(\%)$ & Kriteria \\
\hline Tujuan & 65,2 & Cukup \\
Permasalahan & 60,3 & Cukup \\
Menyikapi masalah & 64,7 & Cukup \\
Sudut pandang & 63,4 & Cukup \\
Informasi & 68,5 & Baik \\
Konsep & 67,9 & Baik \\
Asumsi & 61,1 & Cukup \\
Alternatif solusi & 64,7 & Cukup \\
Interpretasi & 61,1 & Cukup \\
Implikasi & 60,3 & Cukup \\
\multicolumn{1}{c}{ Rerata Skor } & 63,7 & Cukup \\
\hline
\end{tabular}

Tabel 3 menujukkan hampir semua indikator kemampuan berpikir kritis mahasiswa pada prasiklus berada pada kategori cukup (rerata skor 63,7\%), kecuali indikator informasi dan indikator konsep yang termasuk kategori baik. Hasil kemapuan berpikir kritis mahasiswa pada prasiklus tersebut dapat digunakan sebagai informasi awal untuk melakukan perbaikan dan menjadi alasan diterapkannya model pembelajaran OIDDE. Hasil perhitungan masing-masing indikator kemampuan berpikir kritis secara klasikal pada Siklus I dapat dilihat pada Tabel 4 berikut.

Tabel 4. Data kemampuan berpikir kritis pada siklus I

\begin{tabular}{lcc}
\hline \multicolumn{1}{c}{ Indikator } & Skor $(\%)$ & Kriteria \\
\hline Tujuan & 76,1 & Baik \\
Permasalahan & 70,5 & Baik \\
Menyikapi masalah & 72,8 & Baik \\
Sudut pandang & 69,4 & Baik \\
Informasi & 75,5 & Baik \\
Konsep & 78,8 & Baik \\
Asumsi & 72,6 & Baik \\
Alternatif solusi & 67,9 & baik \\
Interpretasi & 75,5 & Baik \\
Implikasi & 70,7 & Baik \\
\multicolumn{1}{c}{ Rerata Skor } & 72,9 & Baik \\
\hline
\end{tabular}

Berdasarkan Tabel 4 dapat diketahui bahwa semua indikator kemampuan berpikir kritis mahasiswa pada siklus I dibandingkan dengan prasiklus (Tabel 3) mengalami peningkatan dari kategori cukup dan baik menjadi baik (nilai rerata $72,9 \%$ ). Kondisi tersebut menjadi pertimbangan bahwa siklus masih perlu dilanjutkan ke siklus berikutnya yaitu siklus II, dengan harapan indikator meningkat dari baik menjadi sangat baik. Perbaikanperbaikan pembelajaran sebagaimana yang telah diuraikan pada bagian sebelumnya dilakukan.

Kemampuan berpikir kritis pada siklus II dari hasil perhitungan secara klasikal disajikan pada Tabel 5 . Berdasarkan Tabel 5 dapat diketahui bahwa hampir semua indikator kemampuan berpikir kritis mahasiswa pada siklus II termasuk dalam kategori sangat baik (rerata skor 82,3\%), kecuali indikator asumsi $(73,6 \%)$ dan alternatif solusi $(72,8 \%)$. 
Tabel 5. Data kemampuan berpikir kritis pada siklus II

\begin{tabular}{lcc}
\hline \multicolumn{1}{c}{ Indikator } & Skor $(\%)$ & Kriteria \\
\hline Tujuan & 82,1 & Baik sekali \\
Permasalahan & 78,1 & Baik \\
Menyikapi masalah & 87,0 & Baik sekali \\
Sudut pandang & 87,7 & Baik sekali \\
Informasi & 88,0 & Baik sekali \\
Konsep & 89,1 & Baik sekali \\
Asumsi & 73,6 & Baik \\
Alternatif solusi & 72,8 & Baik \\
Interpretasi & 82,1 & Baik sekali \\
implikasi & 82,1 & Baik sekali \\
\multicolumn{1}{c}{ Rerata Skor } & 82,3 & Baik sekali \\
\hline
\end{tabular}

Berdasarkan data dari Tabel 3, Tabel 4, dan Tabel 5 maka kita dapat menghitung total peningkatan masing-masing indikator keterampilan berpikir kritis mahasiswa dari prasiklus sampai siklus 2. Data peningkatan disajikan pada Gambar 3.

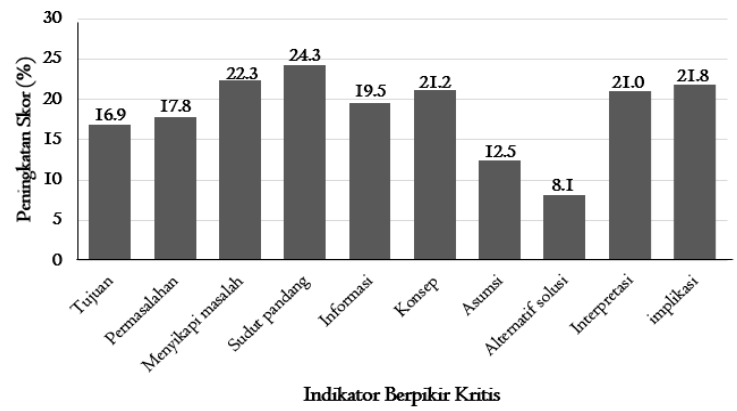

Gambar 3. Data peningkatan setiap indikator kemampuan berpikir kritis mahasiswa

Kita dapat pula menghitung peningkatan rerata skor atau membandingkan rerata skor pada prasiklus, Siklus I, dan Siklus II, seperti disajikan pada Gambar 4.

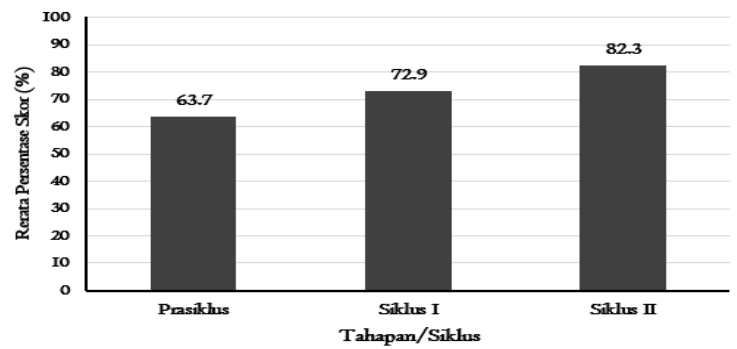

Gambar 4. Data peningkatan kemampuan berpikir kritis mahasiswa pada setiap siklus

Berdasarkan data pada Tabel 3, Tabel 4, Tabel 5, dan Gambar 3, terlihat bahwa Model Pembelajaran OIDDE mampu meningkatkan kemampuan berpikir kritis mahasiswa yang menempuh mata kuliah Pengetahuan Lingkungan. Semua indikator keterampilan berpikir kritis meningkat setiap siklusnya, baik pada Siklus I dan terlebih lagi pada Siklus II. Secara rerata skor, pada Siklus I semua indikator sudah termasuk pada kategori baik, sedangkan pada Siklus II termasuk kategori sangat baik. Rerata kemampuan berpikir kritis mahasiswa meningkat dari $63,7 \%$ pada prasiklus menjadi $72,9 \%$ pada Siklus I (peningkatan sebesar 9,2\%) dan menjadi 82,3\% pada Siklus II (peningkatan sebesar 9,4\%). Total peningkatan kemampuan berpikir kritis dari prasiklus sampai Siklus II sebesar $18,6 \%$.

Hasil penelitian ini sejalan dengan Setyawan (2017) bahwa penerapan Model Pembelajaran OIDDE pada Matakuliah Zoologi Vertebrata dalam analisis yang sederhana dapat meningkatkan kemampuan berpikir kritis mahasiswa semester III (kelas III-C) Pendidikan Biologi Universitas Muhammadiyah Malang tahun ajaran 2015-2016 sebesar 7\% sampai dengan 10\%. Penerapan Model Pembelajaran OIDDE pada Matakuliah Zoologi Vertebrata juga dapat meningkatkan hasil belajar mahasiswa Prodi Pendidikan Biologi Universitas Muhammadiyah Malang dengan ketuntasan belajar $100 \%$.

Materi yang disajikan oleh dosen model dalam pembelajaran mata kuliah Pengetahuan Lingkungan ini adalah Permasalahan Lingkungan dan Strategi Pemgembangan Lingkungan. Menurut Siswandari, Hindun, \& Sukarsono (2016) proses pembelajaran akan menarik apabila pengajar mampu menghadirkan materi atau permasalahan yang kontekstual sehingga peserta didik akan cepat terlibat dalam setiap prosesnya karena materi dekat dengan kehidupan mereka. Sejalan dengan itu, dalam pandangan Susetyarini, Wahyuni, \& Latifa (2015) dan H. Husamah (2015) pembelajaran yang didesain dengan menghadirkan problem lingkungan dan menuntut mahasiswa untuk mencari solusi kreatif-inovatif akan membuat mereka semakin peka dan sensitif karena pada dasarnya pembelajaran itu membuat mereka sadar. Mereka akan menggali pengalamanpengalaman, pengetahuan dan teori yang telah dikonsturksi sebelumnya menjadi suatu ide yang solutif. Tahapan proses berpikir kritis itu, menurut Yanfa'ani, Maridi, \& Dwiastuti (2015) diawali dengam mencari makna dan pemahaman terhadap sesuatu, kemudian mempertimbangkan keputusan dan lalu memberi solusi terhadap suatu permasalahan.

Sehubungan dengan hal tersebut, efektivitas Model Pembelajaran OIDDE dalam meningkatkan kemampuan berpikir kritis dapat diduga karena pada tahapan atau fasenya mendorong mahasiswa untuk melakukan kegiatan belajar yang terintegrasi pada peningkatan pengetahuan dan menerapkan ilmu pengetahuan yang kemudian diintegrasikan pada pengalaman belajar sehari-hari mahasiswa. Kelima fase dalam Model Pembelajaran OIDDE, yaitu Orientation, Identify, Discussion, Decision, dan Engage in behavior mampu memenuhi persyaratan tersebut. Oak (2009) menyatakan bahwa keterampilan berpikir kritis akan berkembang 
melalui pengolahan kebiasaan berpikir analisis dan berpikir strategik. Kemampuan itu ditingkatkan dengan membangun kebiasaan untuk mengalisis situasi yang kritis. Mengembangkan kemampuan memecahkan masalah dan mengembangkan keterampilan berargumentasi mahasiswa merupakan strategi yang sangat tepat dalam meningkatkan keterampilan berpikir kritis.

Hasil penelitian ini juga menguatkan temuan penelitian Fariati et al (2017) bahwa Model Pembelajaran OIDDE efektif dalam memberikan dan menanamkan pengetahuan terkait permasalahan perilaku seks pranikah pada remaja. Hal ini menunjukkan bahwa Model Pembelajaran OIDDE yang diimplementasikan kepada para siswa mampu memberikan pemahaman dan akhirnya mereka mampu memilih alternatif jawaban yang paling baik atau paling tepat, karena adanya penguatan terhadap pertimbangan etis mereka melalui pembelajaran ini. Patut diduga bahwa kemampuan siswa dalam memilih alternatif perilaku dan melakukan pertimbangan etis tidak lain adalah kemampuan berpikir kritis mereka yang terbina melalui Model Pembelajaran OIDDE. Inilah yang menghubungkan antara hasil penelitian ini dengan hasil penelitian Fariati et al (2017). Dengan demikian dapat dikatakan bahwa pelaksanaan model pembelajaran OIDDE dengan tepat sesusai dengan tahapan seharusnya akan merangsang munculnya kemampuan berpikir kritis mahasiswa dan bila dilakukan terus menerus akan meningkatkan kualitas berpikir kritis mereka.

Fase atau tahapan dalam model Pembelajaran OIDDE mampu mestimulasi sepuluh indikator keterampilan berpikir kritis. Hal ini sejalan dengan pandangan Machin (2014) bahwa pembelajaran yang tepat akan dapat memberikan pengalaman bermakna bagi mahasiswa, karena mereka tidak hanya memahami, tetapi juga meresapi, menginternalisasi, dan mengaktualisasikan dalam kehidupan sehari-hari. Menurut Suharyat (2009) meresapi dan menginternalisasi berhubungan dengan penyikapan masalah, sudut pandang, dan asumsi seseorang, sedangkan menurut Nasihin (2015) internalisasi juga berhubungan dengan alternatif solusi yang diambil dan interpretasi, sementara aktualisasi adalah istilah lain dari implikasi perilaku atau sikap yang diambil seseorang.

Model Pembelajaran OIDDE mendorong mahasiswa untuk aktif mengidentifikasi masalah, memilih alternatif pemecahan masalah, dan mewujudkan dalam sikap. Hal tersebut dilaksanakan dalam kegiatan secara individu maupun dalam kelompok, baik dalam kondisi dalam pengawasan dosen model maupun secara mandiri tanpa tergantung ada tidaknya dosen model. Hal ini akan membantu mahasiswa untuk menjadi calon generasi yang berkarakter di masa depan, yang bisa bekerja secara mandiri namun tetap mampu bekerja secara berkelompok atau kooperatif. Menurut Surya (2013) berpikir kritis merupakan sebuah proses aktif dan teratur untuk memahami informasi secara mendalam sehingga membentuk sebuah keyakinan kebenaran informasi yang didapat atau pendapat yang disampaikan. Berpikir kritis dapat menumbuhkan kemampuan mengidentifikasikan prasangka, masalah yang bias (berpihakan), menafsirkan propaganda, adanya unsur kebohongan, distorsi (menyesatkan), informasi yang salah (misinformasi), egosentrisme, dan lan-lain.

Kegiatan Orientation dan Identify memberikan peluang diskusi mahasiswa mulai terarah dan sistematis karena masing-masing mahasiswa memiliki data berupa informasi tentang fakta-fakta. Kegiatan Discussion mendorong mahasiswa secara langsung menggunakan pengalaman dan pengetahuannya untuk mencari alternaif solusi dan tindakan bagi dirinya dan orang lain. Hal inilah yang menjadikan meningkatnya kemampuan berpikir kritis secara nyata. Pernyataan ini sejalan dengan Karyana (2013) bahwa pengembangan kemampuan berpikir itu tidak dapat dilakukan hanya dengan melalui metode ceramah atau penjelasan saja, tetapi harus banyak melatih dan mempraktekan keterampilan berpikir melalui pembelajaran-pembelajaran aktif berbasis masalah dan studi kasus dalam suasana diskusi multi arah.

Kegiatan pembelajaran yang didesain dimana peserta didik mengindentifikasi masalah akan mendorong peningkatan kemampuan berpikir kritis (Atmojo, 2009). Pembiasaan berpikir kritis menjadi penentu kemampuan dalam menjawab permasalahan pada saat mengikuti kegiatan pembelajaran (Ekawati, Susetyarini, Pantiwati, \& Husamah, 2015; Jariyah, 2017). Aktivitas mengidentifikasi mendorong berpikir kritis karena menuntut kemampuan menganalisis suatu masalah. Pikiran harus terbuka, jelas dan berdasarkan fakta. Seorang pemikir kritis harus mampu memberi alasan atas pilihan keputusan yang diambilnya. Ia harus bisa menjawab pertanyaan mengapa keputusan seperti itu diambil (Harsanto, 2005).

Kegiatan Decision mengkondisikan mahasiswa untuk mengambil keputusan pemecahan masalah. Hal ini akan menjadi bekal berharga apabila mahasiswa calon guru ini terjun ke dunia nyata menjadi pendidik masa depan. Menurut Snyder \& Snyder (2008) agar efektif di tempat kerja (dan kehidupan pribadi mereka), mahasiswa harus dapat memecahkan masalah untuk membuat keputusan 
efektif; mereka harus bisa berpikir kritis. Hal senada menurut Wehmeyer (2007) bahwa kemampuan mahasiswa untuk memecahkan masalah sangat penting bagi keberhasilan mereka dalam pendidikan dan kehidupan. Kapasitas ini menjadi semakin penting dalam konteks upaya reformasi pendidikan, sebagai upaya menciptakan generasi handal di masa depan.

Kegiatan Engage in behavior menuntut mahasiswa berperilaku sebagaimana keputusan yang ditetapkan secara verbal. Menurut Peter (2012) seseorang yang lemah dalam berpikir kritis cenderung memilih perilaku sederhana, dan sebaliknya kemampuan berpikir kritis menuntut mereka memilih perilaku yang berarti. Oleh karena itu menurut McCormick et al (2015) pendidik harus mencoba memenuhi tujuan bersama membantu mahasiswa untuk mengembangkan dan meningkatkan kemampuan berpikir kritis dan pemecahan masalah mereka. Mahasiswa yang aktif terlibat lebih termotivasi untuk melakukan dengan baik. Pembelajaran kolaboratif yang didesain dalam kelompok kecil dan menuntut mereka untuk melakukan pemecahan masalah terbukti efektif dalam meningkatkan keterlibatan, minat, dan persepsi mengenai suatu nilai dan esensi pelajaran.

\section{Simpulan}

Hasil penelitian menunjukkan bahwa 1) model pembelajaran OIDDE telah dilaksanakan sesuai sintaks, dimana ada perbaikan proses pada siklus II berdasarkan masukan para observer pada Siklus I, dan 2) Dengan membandingkan antara data pada prasiklus dengan siklus II maka kesepuluh indikator keterampilan berpikir kritis mengalami peningkatan. Hampir semua indikator pada siklus 2 termasuk dalam sangat baik, kecuali asumsi dan alternatif solusi yang termasuk kategori baik. Hal ini menunjukkan model pembelajaran OIDDE dapat meningkatkan keterampilan berpikir kritis mahasiswa pendidikan biologi. Berdasarkan hal tersebut dapat disarankan bahwa perlu penelitian lebih lanjut untuk mengetahui bagaimana model pembelajaran OIDDE bila dikaitkan dengan upaya peningkatan kemampuan berpikir kreatif, metakognitif, self regulation, motivasi, pengambilan sikap etis, atau pun lainnya.

\section{Daftar Pustaka}

Afandi, Sugiyarto, \& Sunarno, W. (2012). Pembelajaran biologi menggunakan pendekatan metakognitif melalui nodel reciprocal learning dan problem based learning ditinjau dari kemandirian belajar dan kemampuan berpikir kritis mahasiswa. INKUIRI, 1(2), 86-92.

Agustina, R., \& Susantini, E. (2010). Penerapan perangkat pembelajaran pencemaran dan pelestarian lingkungan untuk melatih keterampilan berpikir kritis. In Prosiding Seminar Nasional Biologi (Vol. 7). Surakarta: Universitas Sebelas Maret.

Arikunto, S. (2001). Dasar-dasar evaluasi pendidikan. Jakarta: Bumi Aksara.

Arikunto, S. (2005). Manajemen penelitian. Jakarta: Rineka Cipta.

Arnyana, I. B. P. (2004). Pengembangan perangkat model belajar berdasarkan masalah dipandu strategi kooperatif serta pengaruh implementasinya terhadap kemampuan berpikir kritis dan hasil belajar siswa sekolah menengah atas pada pelajaran ekosistem. (Disertasi Doktor yang tidak diterbitkan). Universitas Negeri Malang, Malang.

Arslan, S. (2012). The influence of environment education on critical thinking and environmental attitude. Procedia -Social and Behavioral Sciences, 55, 902-909. https://doi.org/10.1016/j.sbspro.2012.09.579

Atmojo, E. P. D. (2009). Upaya peningkatan aktivitas berpikir kritis melalui model tugas terstruktur dan kuis ( PTK pembelajaran matematika kelas VIII MTsN Cepogo Boyolali). (Skripsi tidak diterbitkan). Universitas Muhammadiyah Surakarta, Surakarta.

BSNP, T. P. P. (2010). Paradigma pendidikan nasional abad XXI. Jakarta: Badan Standar Nasional Pendidikan.

Djamarah, S. B. (2000). Guru dan Anak Didik dalam Interaksi Edukatif. Jakarta: Rineka Cipta.

Doig, B., \& Groves, S. (2011). Japanese lesson study: Teacher professional development through communities of inquiry. Mathematics Teacher Education and Development, 13(1), 77-93.

Ekawati, R., Susetyarini, E., Pantiwati, Y., \& Husamah, H. (2015). Peningkatan hasil belajar dan kemampuan berpikir kritis dengan model pembelajaran cooperative integrated reading and composition (CIRC). JPBI: Jurnal Pendidikan Biologi Indonesia, 1(3), 298-306. https://doi.org/10.22219/JPBI.V1I3.2662. G3339 
Fariati, E., Hudha, A. M., \& Husamah, H. (2017). Pengetahuan dan keputusan etis siswa SMK Negeri 6 malang terhadap permasalahan perilaku seks pra nikah melalui model pembelajaran OIDDE. In Prosiding Seminar Nasional III Tahun 2017. Malang: Universitas Muhammadiyah Malang.

Harsanto, R. (2005). Melatih anak berpikir analitis, kritis, dan kreatif. Jakarta: Gramedia.

Hartiwiningsih. (2009). Penegakan hukum pidana lingkungan. Universitas Sebelas Maret, Surakarta.

Hudha, A. M. (2015). Kajian pengetahuan bioetika dan kemampuan pengambilan keputusan etis mahasiswa calon guru biologi. In Prosiding Seminar Nasional Pendidikan Biologi (hal. 530-538). Malang: Universitas Muhammadiyah Malang.

Hudha, A. M., Amin, M., Bambang, S., \& Akbar, S. (2016a). Model pembelajaran OIDDE untuk pembelajaran bioetika. In Prosiding Seminar Nasional II Tahun 2016. Malang: Universitas Muhammadiyah Malang.

Hudha, A. M., Amin, M., Bambang, S., \& Akbar, S. (2016b). Telaah model-model pembelajaran dan sintaksnya sebagai upaya pengembangan model pembelajaran "OIDDE." JPBI: Jurnal Pendidikan Biologi Indonesia, 2(2), 109-124. https://doi.org/10.22219/JPBI.V2I2.3448. G4169

Husamah, H. (2015). Blended project based learning: Metacognitive awareness of biology education new students. Journal of Education and Learning, $9(4), 274-281$. https://doi.org/10.11591/EDULEARN. V9I4.2121

Husamah, H. (2015). Blended project based learning: Thinking skills of new students of biology education department (environmental sustainability perspective). Jurnal Pendidikan IPA Indonesia, 4(2), 110-119. https://doi.org/10.15294/JPII.V4I2.3878

Husamah, H. (2016). Penerapan tugas menulis jurnal belajar terhadap nilai akhir mahasiswa pada mata kuliah pengantar pendidikan di Prodi Pendidikan Biologi FKIP - UMM. In Prosiding Seminar Nasional II Tahun 2016 (hal. 1175-1181). Malang: Universitas Muhammadiyah Malang.

Husamah, H., \& Pantiwati, Y. (2014). Cooperative learning STAD-PjBL: Motivation, thinking skills, and learning outcomes in biology students. International Journal of Education Learning \& Development (IJELD), 2(1), 77-94

Jariyah, I. A. (20I7). The effect of inquiry combined science-technology-society (STS) learning to enhance critical thinking skills on science. JPBI: Jurnal Pendidikan Biologi Indonesia, 3(1), 1-9. https://doi.org/10.22219/JPBI.V3I1.3888.G 4602

Karjalainen, A., Alha, K., \& Jutila, S. (2006). Give me time to think: determining student workload in higher education. Oulun Yliopisto, Finland: Oulu University Press.

Karyana, N. (2013). Meningkatkan kemampuan berpikir kritis melalui penggunaan metode studi kasus. Bandung: Widyaiswara LPMP Jawa Barat.

Kemmis, S., McTaggart, R., \& Nixon, R. (2013). The action research planner: doing critical participatory action research. London: Springer Science \& Business Media.

Khoiriyah, S., \& Ristianti, R. (2011). Kesadaran lingkungan dan motivasi berprestasi siswa SMA Negeri I Depok tahun 2010/2011 dalam kegiatan Toyota EcoYouth (TEY). BIOEDUKASI, 4(2), 13-22.

Kusni, M. (2010). Implementasi sistem pembelajaran blended learning pada kuliah AE3121 getaran mekanik di Program Studi Aeronotika dan Astronotika. In Seminar Nasional Tahunan Teknik Mesin (SNTTM) ke-9.

Lewis, C. C. (2002). Lesson study: a handbook of teacher-led instructional change. Philadelphia: Research for Better Schools, Inc.

Machin, A. (2014). Implementasi pendekatan saintifik, penanaman karakter dan konservasi pada pembelajaran materi pertumbuhan. Jurnal Pendidikan IPA Indonesia, $\quad 3(1), \quad 28-35$. https://doi.org/10.15294/jpii.v3i1.2898

McCormick, N. J., Clark, L. M., \& Raines, J. M. (2015). Engaging students in critical thinking and problem solving: A brief review of the literature. Joumal of Studies in Education, 5(4), 100-113. https://doi.org/10.5296/jse.v5i4.8249

Minarno, E. B. (2012). Pembelajaran bioetika sebagai pengawal perkembangan biologi modern dan penyelamatan lingkungan 
hidup. Jurnal el-Hayah, 3(1). https://doi.org/10.18860/elha.v3i1.2217

Nasihin, N. (2015). Internalisasi nilai-nilai agama islam dalam pembinaan akhlak mulia. Ummul Quro, 5(1), 1-10.

Oak, M. (2009). Simple Yet Practical Tips on Developing Critical Thinking Skills. Diambil 12 September 2017, dari https://www.buzzle.com/articles/developi ng-critical-thinking-skills.html

Pantiwati, Y. (2015). Pemanfaatan lingkungan sekolah sebagai sumber belajar dalam lesson study untuk meningkatkan metakognitif. JURNAL BIOEDUKATIKA, 3(1), 2732.

https://doi.org/10.26555/bioedukatika.v $3 \mathrm{i} 1.4144$

Pary, C. (2010). Keanekaragaman dan kepadatan kepiting bakau (Scylla spp) pada kawasan hutan mangrove teluk kotania kabupaten seram bagian barat sebagai bahan pengembangan materi praktikum ekologi $d i$ perguruan tinggi. (Thesis tidak diterbitkan). Universitas Muhammadiyah Malang, Malang.

Peter, E. E. (2012). Critical thinking: Essence for teaching mathematics and mathematics problem solving skills. African Journal of Mathematics and Computer Science Research, 5(3), 39-43. https://doi.org/10.5897/AJMCSR11.161

Prasetiyo, N. A., \& Perwiraningtyas, P. (2017). The Development of Environment based Textbook in Biology Course at Tribhuwana Tunggadewi University. JPBI: Jurnal Pendidikan Biologi Indonesia, 3(1), 19-27. https://doi.org/10.22219/JPBI.V3I1.396 9.G4604

Puspitasari, E., Sumarmi, S., \& Amirudin, A. (2016). Integrasi Berpikir Kritis dan Peduli Lingkungan melalui Pembelajaran Geografi dalam Membentuk Karakter Peserta Didik SMA. Jurnal Pendidikan: Teori, Penelitian, dan Pengembangan, 1(2), 122-126.

Quinn, C. (2012). Studies on Critical Thinking for Environmental Ethics. University of Nebraska. Diambil dari http://digitalcommons.unl.edu/aglecdiss

Rosnawati, R. (2012). Berpikir kritis melalui pembelajaran matematika untuk mendukung pembentukan karakter siswa. In Seminar Nasional Pendidikan (hal. 1-9). Yogyakarta: Universitas Sanata Dharma.
Rozak, A., \& Fauziah, E. (2013). Implementasi lesson study sebagai upaya peningkatan kompetensi pedagogik guru bahasa indonesia di SMP kabupaten Cirebon. Jurnal Pendidikan Bahasa dan Sastra, 13(1), 1-14.https://doi.org/10.17509/bs_ppbsp.v13i1.754

Saragih, S. (2008). Mengembangkan keterampilan berfikir matematika. In Prosiding Seminar Nasional Matematika dan Pendidikan Matematika. Yogyakarta: Universitas Negeri Yogyakarta.

Setyaningrum, Y., \& Husamah, H. (2011). Optimalisasi penerapan pendidikan karakter di sekolah menengah berbasis keterampilan proses: Sebuah perspektif guru IPA-Biologi. Jurnal Penelitian dan Pemikitan Pendidikan, 1(1), 69-81.

Setyawan, D. (2017). Penerapan model pembelajaran OIDDE pada matakuliah zoologi vertebrata untuk meningkatkan kemampuan berfikir kritis dan hasil belajar mahasiswa pendidikan biologi Universitas Muhammadiyah Malang. In Prosiding Seminar Nasional III Tahun 2017 (hal. 196203).Malang: Universitas Muhammadiyah Malang.

Sidharta, A., \& Darliana, D. (2005). Keterampilan berfikit. Bandung: P3GIPA, Ditjend Dikdasmen Depdiknas.

Siswandari, A. M., Hindun, I., \& Sukarsono, S. (2016). Phytoremediation of phosphate content in liquid laundry waste by using echinodorus paleafolius and equisetum hyemale used as biology learning resource. JPBI: Jurnal Pendidikan Biologi Indonesia, 2(3), 222-230. https://doi.org/10.22219/jpbi.v2i3.3860

Snyder, L. G., \& Snyder, M. J. (2008). Teaching critical thinking and problem solving skills. The Delta Pi Epsilon Joumal, 50(2), 90-99.

Suharyat, Y. (2009). Hubungan antara sikap, minat dan perilaku manusia. Jurnal Region, 1(3), 1-19.

Surya, H. (2013). Cara belajar orang genius. Jakarta: Elexmedia.

Susetyarini, R. E., Wahyuni, S., \& Latifa, R. (2015). Kemampuan berpikir kritis mahasiswa pada matakuliah embriologi dan reproduksi hewan melalui lesson study. In Prosiding Seminar Nasional Pendidikan Biologi 2015 (hal. 774-781). Malang: Universitas Muhammadiyah Malang.

Susilo, H. (2009). Combining lesson study (LS) and classroom action research (CAR) for 
teacher professional development. CoSMEd 2009 Proceedings, 77-84.

Syamsuri, I., \& Ibrohim. (2011). Lesson study (studi pembelajaran). Malang: UM Press.

Turista, D. D. R. (2017). Biodegradation of organic liquid waste by using consortium bacteria as material preparation of environmental pollution course textbook. Jurnal Pendidikan Biologi Indonesia, 3(2), 95. https://doi.org/10.22219/jpbi.v3i2.4322. g4734
Wehmeyer, M. L. (2007). Promoting selfdetermination in students with developmental disabilities. New York: Guilford Press.

Yafie, A. (2006). Merintis fiqh lingkungan hidup. Jakarta: Yayasan Amanah.

Yanfa'ani, P. S., Maridi, \& Dwiastuti, S. (2015). The influence of active knowledge sharing based contexstual learning models toward biology critical thingking. Jurnal Pendidikan Biologi, 7(1), 28-39. 